\title{
Effect of Spent Engine Oil on the Germination Ability of Eleven Accessions of African Yam Bean Seeds (Sphenostylis sternocarpa Hochst ex A. Rich) Harms
}

\author{
${ }^{1}$ Osuagwu, A.N. and ${ }^{2}$ Nwofia, G.E. \\ ${ }^{l}$ Department of Plant Science and Biotechnology, College of Natural Sciences, ${ }^{2}$ Department of Agronomy, \\ College of Crop and Soil Sciences, Michael Okpara University of Agriculture, Umudike, Umuahia, Abia State, \\ Nigeria.
}

\begin{abstract}
Laboratory studies were carried out in 2011 at the Plant Science and Biotechnology Laboratory of the College of Natural and Applied Sciences of Michael Okpara University of Agriculture Umudike to investigate the germination ability of eleven accessions of African yam bean seeds in spent engine oil (SEO). The experiment was laid out in Complete Randomized Design (CRD). Seeds of the eleven accession of African yam bean were presoaked in water for 24hours and thereafter soaked in spent engine oil for varying hours 0,1 , 2, 4, 8 and 16 hours. The seeds were placed in Petri dish lined with moist tissue paper. The result obtained showed that the germination percentage, days to germination and rate of germination of the AYB accessions were time and accession dependent. The germination ability of seeds decreased as number of hours soaked in spent engine oil increased. AYB-11, AYB-04, AYB-03 and AYB-07 were more tolerant to oil among the African yam bean accessions studied hence could be considered to be used to boost food security in oil producing areas of the Niger Delta.
\end{abstract}

Key words: African yam bean, spent engine oil, germination ability,

\section{Introduction}

African yam bean (Sphenostylis sternocarpa Ex. A. Rich Harms) is an underutilized food legume crop in the tropics that is not popular as other major food legumes crop (Azeke et al., Moyib et al., 2008). African yam bean (AYB) like other tuberous legumes is a member of the Fabaceae family. African yam bean is cultivated mainly for home consumption and only about $30 \%$ of the dry grain produced is sold. It is also planted for soil restoration (Saka et al .,2007). African yam bean is a good source of protein, fiber and carbohydrate. It is also rich in minerals such as phosphorous, Iron and potassium and contains some anti-nutrients such as trypsin inhibitor, phytate, tannin and other alkaloids (Nwokolo, 1987; Ajibade et al., 2005; Fasoyiro et al., 2006). African yam bean is usually cooked and eaten the alone with yam, maize and rice. It can be used to replace cowpea in food preparation especially during the lean period when food is scarce among the rural farmers (Akande, 2009). One limit to the use of African yam bean is that the seeds require a long cooking time because of the hard testa. This is energy and time consuming (Akande, 2009).

Crude oil varies in appearance and composition from one kind to another (Craig 2003, Akaniwor et al., 2007). Effect of auto mechanic due to indiscriminate disposal of spent oil is inevitable (Ogbuehi et al., 2011). Agbogidi and Ejaemete (2005) observed that oil in soil deleterious effect on the biological, chemical and physical properties of the soil depending on the dose, type of the oil and factors. There are relatively large amounts of the hydrocarbon in the used oil including the highly toxic polycyclic aromatic hydrocarbons (Okonokhua et al., 2007). When oil is applied to soil microbiological components of soil are usually negatively affected Benka-Coker and Ekudayo (1997). Although some research work have been conducted on the effects of spent lubricating oil on the germination of some economic crop (Ogbo, 2009; Anoliefo et al., 2001; Okonokhus et al., 2007; Srujana and Khan, 2010; Adedakun and Atega, 2007). But there is no information on the effect of spent engine oil on the germination ability of African yam bean hence the objective of this study was to establish germination ability of African yam bean in spent engine oil.

\section{Materials And Method}

The experiment carried was out in 2011 at the Plant Science and Biotechnology laboratory of the College of Natural and Applied Sciences, of Michael Okpara University of Agriculture Umudike, Umuahia, Abia State. Spent engine oil was obtained from a mechanic workshop in Umuahia, Abia State. Seeds of eleven accessions of Sphenostylis sternocarpa collected from different locations were used to determine the germination ability of African yam bean in spent engine oil (Table 1). The seeds were subjected to viability test using floatation technique. The floatation technique was used to remove insect-damage or empty seeds (Mahmut, 2010). The samples were randomly taken from homogenous population of each seed type, the eleven 
accessions of African yam bean was presoaked in water for 24 hours and thereafter in $100 \%$ spent engine oil for varying periods of time $(0,1,2,4,8,16$ hours $)$ and then allowed to germinate on moist tissue paper placed in Petri-dishes. For each treatment, a total of 20 seeds was used and replicated three times. Experimental design was Complete Randomized Design (CRD). Readings was taken at 24 hours interval and emergence of radicles was used as a critical stage of germination (Agbogidi, 2010).

\section{DETERMINATION OF GERMINATION PERCENTAGE}

Percentage germination was determined using the method of Agbogidi (2010):

Number of seedlings that sprouted $\times 100$

Number of seeds planted

\section{DETERMINATION OF DAYS TO GERMINATION}

Days to germination were determined using the method of Marli and Santana (2006).

Days to germination as mean length of incubation time. It is a measurement of the average length required for maximum germination of a seed lot, and is expressed in terms of the unit used in making germination counts (hours or days)

\section{DETERMINATION OF RATE OF GERMINATION}

The germination rate was calculated as the coefficient of velocity of germination, denoting it as $\mathrm{CVG}=\mathrm{V}=\underline{\mathrm{CV}}=\underline{1}$

Where $\mathrm{t}=$ mean germination time, and CV coefficient of velocity.

In time, since the mean rate increases and decreases with $1 / \mathrm{t}$ not with $\mathrm{t}$. The rate of germination was determined using Marli and Garcia (2006) method.

\section{DATA ANALYSIS}

Data were separately subjected to analysis of variance using GENSTAT Discovery Edition 4 (GENSTAT, 2007) and significant differences were determined using least significant differences (LSD) at 5\% level probability.

\section{Results And Discussion}

The results of the effect of spent engine oil on eleven accessions of African yam bean seeds (Sphenostylis sternocarpa) are shown in tables 2-4.

Most of the African yam bean accessions sown on the uncontaminated Petri dish germinated on the $3^{\text {rd }}$ day after sowing with some of the accessions germinated on the $2^{\text {nd }}$ and $5^{\text {th }}$ day. There was highly significant difference $(\mathrm{P}<0.01)$ with seeds contaminated with spent engine oil $(\mathrm{SEO})$. The germination percentage decreased as the number of hours increased (Table 1). This could be as a result of volatile fractions of oil which have high wetting capacity and penetrating power; it enters the seed coat and kills the embryo. In addition, as oil contaminated soils become compact they may lead to poor wetting ability and increased amount of toxic substances which may result to decrease in germination (Srujana and Anisa, 2010). The presence of spent oil in the soil-plant micro-environment affects normal soil chemistry wherein nutrient release and uptake as well as amount of water get reduced (Nwoko et al., 2007; Odejgba and Sadiq, 2002). Agbogidi (2010) had reported that oil effect on plants are species and variety dependent which agrees with the observation made on this work at 16 hours, some of the accessions were not affected by the toxicity of the oil hence germinated.

The African yam bean accession soaked in spent engine oil for more than 2 hours germination percentage reduced drastically. None of the African yam bean accession germinated while still soaked in spent engine oil. The oil could have endangered the life of the seed embryo and hence lead to the loss of seed viability. This result is in agreement with Agbogidi (2010), Ogbo(2009), Adekakun and Atage(2007), Anoliefo et al., (2001), Srujana and Khan, (2010), Okonokhua et al.,(2009). The result also showed that AYB-11, AYB04, AYB-09, AYB-03, AYB-01, AYB-07 were more tolerant to oil levels in this study. Agbogidi and Nweke(2005), Ogbo,(2009) and Agbogidi(2010) had reported that oil effect on plants are species and variety dependent. Adam and Duncan (2002) and Anoliefo et al.,(2001).

\section{Conclusion}

The observation made from this research showed that AYB-11, AYB-04, AYB-09, AYB-03, AYB-01, AYB-07 were more tolerant to different level of spent engine oil. Therefore, they can be used to boost food security in Niger Delta area of Nigeria 
TABLE 1

Place of collection, collector, helium colour and seed colour of Sphenostylis sternocarpa (African yam bean) used in the study

\begin{tabular}{|c|c|c|c|c|c|c|}
\hline S/No & Place of collection & State & $\begin{array}{l}\text { Accession } \\
\text { number }\end{array}$ & Collector & Seed colour & Hiliumcolour \\
\hline 1 & Etitiama-Nkporo & Abia & AYB-01 & Osuagwu, A. & Brown, White & Black, Brown \\
\hline 2 & Etitiulo-Bende & Abia & AYB-02 & Osuagwu, S. & $\begin{array}{l}\text { Speckled, } \\
\text { White }\end{array}$ & Brown, Black \\
\hline 3 & Abam & Abia & AYB-03 & Osuagwu, S. & White & Brown \\
\hline 4 & Amauwom & Abia & AYB-04 & Osuagwu, A & White, Black & Black, Brown \\
\hline 5 & Alayi & Abia & AYB-05 & Osuagwu, A. & White, Brown & $\begin{array}{l}\text { Brown, } \\
\text { Brown }\end{array}$ \\
\hline 6 & Itu & Akwa Ibom & AYB-06 & Osuagwu, S. & Brown, White & $\begin{array}{l}\text { Brown, } \\
\text { Brown }\end{array}$ \\
\hline 7 & Ngor-Okpuala & Imo & AYB-07 & Okwulehie, I. C. & White, Brown & Black \\
\hline 8 & Akaeze & Ebonyi & AYB-08 & Nkaa, F. & Marbled & Brown \\
\hline 9 & Ishiagu & Ebonyi & AYB-09 & Okoro, I. A. & $\begin{array}{l}\text { Brown, } \\
\text { Marbled }\end{array}$ & Black, Brown \\
\hline 10 & Nsukka & Enugu & AYB-10 & Olaitan, T. & Milky & Brown \\
\hline 11 & Ankpa & Kogi & AYB-11 & Abu, A. & White, Marbled & Black, Brown \\
\hline
\end{tabular}

TABLE 2

Germination Percentage of African yam bean seeds in spent engine oil

\begin{tabular}{|c|c|c|c|c|c|c|}
\hline Accessions & Control & 1hour & 2hour & 4hour & 8hour & 16hour \\
\hline AYB-01 & 100 & 63.30 & 56.70 & 40.00 & 23.30 & 13.33 \\
\hline AYB-02 & 100 & 90.00 & 80.00 & 70.00 & 60.00 & 0.00 \\
\hline AYB-03 & 100 & 66.70 & 30.00 & 36.70 & 20.00 & 8.33 \\
\hline AYB-04 & 100 & 80.00 & 63.30 & 46.70 & 30.00 & 20.33 \\
\hline AYB-05 & 100 & 0.0 & 0.0 & 0.0 & 0.0 & 0.0 \\
\hline AYB-06 & 100 & 0.0 & 0.0 & 0.0 & 0.0 & 0.0 \\
\hline AYB-07 & 100 & 53.30 & 40.70 & 33.30 & 20.00 & 8.33 \\
\hline AYB-08 & 100 & 0.0 & 0.0 & 0.0 & 0.0 & 0.0 \\
\hline AYB-09 & 100 & 66.70 & 46.70 & 30.00 & 18.30 & 8.33 \\
\hline AYB-10 & 100 & 83.3 & 86.7 & 70.00 & 50.00 & 0.0 \\
\hline AYB-11 & 100 & 100 & 100 & 98.30 & 91.70 & 90.00 \\
\hline LSD 0.01 & NS & $19.96 * *$ & $17.44 * *$ & $15.42 * *$ & $10.00 * *$ & $2.762 * *$ \\
\hline
\end{tabular}

TABLE 3

Days to germination of African yam bean accession soaked in spent engine oil at different hours

\begin{tabular}{|c|c|c|c|c|c|c|}
\hline Accessions & Control & 1hour & 2hour & 4hour & 8hour & 16hour \\
\hline AYB-01 & 100 & 63.30 & 56.70 & 40.00 & 23.30 & 13.33 \\
\hline AYB-02 & 100 & 90.00 & 80.00 & 70.00 & 60.00 & 0.00 \\
\hline AYB-03 & 100 & 66.70 & 30.00 & 36.70 & 20.00 & 8.33 \\
\hline AYB-04 & 100 & 80.00 & 63.30 & 46.70 & 30.00 & 20.33 \\
\hline AYB-05 & 100 & 0.0 & 0.0 & 0.0 & 0.0 & 0.0 \\
\hline AYB-06 & 100 & 0.0 & 0.0 & 0.0 & 0.0 & 0.0 \\
\hline AYB-07 & 100 & 53.30 & 40.70 & 33.30 & 20.00 & 8.33 \\
\hline AYB-08 & 100 & 0.0 & 0.0 & 0.0 & 0.0 & 0.0 \\
\hline AYB-09 & 100 & 66.70 & 46.70 & 30.00 & 18.30 & 8.33 \\
\hline AYB-10 & 100 & 83.3 & 86.7 & 70.00 & 50.00 & 0.0 \\
\hline AYB-11 & 100 & 100 & 100 & 98.30 & 91.70 & 90.00 \\
\hline LSD 0.01 & NS & $19.96 * *$ & $17.44 * *$ & $15.42 * *$ & $10.00 * *$ & $2.762 * *$ \\
\hline
\end{tabular}

$\mathrm{NS}=$ Not Significant $* *=0.01$ 
TABLE 4

Rate of germination of African yam bean accessions

\begin{tabular}{|c|c|c|c|c|c|c|}
\hline Accessions & Control & 1hour & 2hour & 4hour & 8hour & 16hour \\
\hline AYB-01 & 36.46 & 26.143 & 28.357 & 38.617 & 26.67 & 11.67 \\
\hline AYB-02 & 26.31 & 33.353 & 12.543 & 22.797 & 23.33 & 0.000 \\
\hline AYB-03 & 31.25 & 20.117 & 25.117 & 33.367 & 20.00 & 08.33 \\
\hline AYB-04 & 20.83 & 33.340 & 29.437 & 20.090 & 30.00 & 20.00 \\
\hline AYB-05 & 31.25 & 0.000 & 0.000 & 0.000 & 0.000 & 0.000 \\
\hline AYB-06 & 29.40 & 0.000 & 0.000 & 0.000 & 30.00 & 11.67 \\
\hline AYB-07 & 20.00 & 33.350 & 33.483 & 80.333 & 20.00 & 08.33 \\
\hline AYB-08 & 31.25 & 0.000 & 0.000 & 0.000 & 0.000 & 0.000 \\
\hline AYB-09 & 40.82 & 26.000 & 51.667 & 70.640 & 36.67 & 15.00 \\
\hline AYB-10 & 16.94 & 31.270 & 29.493 & 28.930 & 15.00 & 08.30 \\
\hline AYB-11 & 30.03 & 30.030 & 30.030 & 30.253 & 20.00 & 26.67 \\
\hline LSD 0.01 & NS & $0.5050 * *$ & $0.7695^{* *}$ & $0.3298 * *$ & $0.2671 * *$ & $0.4532 * *$ \\
\hline
\end{tabular}

NS=Not Significant $* *=0.01$

\section{References}

[1]. Adams, G and Duncan, H. (2002). Influence of diesel fuel on seed germination. Environ. Pollut. 10:363-370.

[2]. Adedokun, O. M. and Ataga, A. E.(2007). Effects of amendments and bio augumentation of soil polluted with crude oil, automotive gasoline oil and spent engine oil on the growth of cowpea (Vigna unguculata L. Walp). Sci. Res. Essay,2(5): 147-149.

[3]. Agbogidi, O. M and Nweke, F. U.(2005). Effects of crude polluted soil on the performance of okra (Abelmoschus esculentus) Moench in Delta State. Afr.J. Nat. Sci. 8:31-35.

[4]. Agbogidi, O. M. (2010). Response of six cultivars of cowpea (Vignaunguiculata (I) walp) to spent engine oil. African Journal of Food Science and Techonology 1(6) : 139-142.

[5]. Akaniwor, J.O., Ayaneleso, A.O. and Manago, C.C.(2007). Effect of different concentrations of crude oil (Bony light) on major food reserves in guinea corn during germination and growth. Scientific Research and Essay 2(4): 127-131.

[6]. Akande, S.R.,(2009).Germplasm characterization of African yam bean southwest Nigeria. Acta Hortic., 806:695-700.

[7]. Amoatey, H.M., Klu, G.Y.P., Bansa, D., Kumaga, F.K., Aboagye, L.M., Bennet, S. O. and Gamedoagbao, D. K. (2000). African yam bean (Sphenostylissternocarpa) A neglected crop in Ghana. West African Journal of Applied Ecology 53-60.

[8]. Anoliefo, G.O., Isikhuemhen, O. S., Agbuna, S.O.(2001). Small scale Industrial village in Benin City, Nigeria: Establishment, failure and physio toxicity assessment of soils from the abandoned site. Water, Air, Soil Pollution, 131:169-183.

[9]. Azeke, M.A., Barbara, F.,Han, B.P., Wilhelm, H. and Thomas, B. (2005). Nutritional value of African yam bean (Sphenostylis sternocarpa): Improvement by lactic acid fermentation. J. Sci. Food Agric., 85(6):963-970.

[10]. Craing, C. F. (2003). Occupational System and Health Administration Washington D.C. 2010.

[11]. Evans, I. D. and Haismer, D. R. (1979). Rheology of gelatinized starch suspension. Journal of Texture Studies 10:347-370.

[12]. Evans,I.M., Boulter, D., Eagleasham, A. Dart, P.(1997). Protein content and quality of tuberous roots of some legumes determined by chemical methods. Qualitas planetarium/ plant food for human nutrition 27(3/4):275-285.

[13]. Fasoyiro, S.B., Ajibade, S. R., Omole, A. J., Adeniyan, O.N., Farinde, E.O.(2006). Proximate, minerals and anti-nutritional factors of some under-utilized grain legumes in south-western Nigeria. Nutriton and Food Science 36: 18-23.

[14]. Genstat Discovery $4^{\text {th }}$ edition (2007). Genstat Procedure Library Release PL18.2 VSN International Ltd.

[15]. Klu, G.Y.P., Amoatey, H.M., Bansa, D. Kumaga, F.K., (2001). Cultivation and use of African yam bean (Sphenostylis sterncarpa) in the Volta Region of Ghana. The Journal of Food Technology in Africa, 6: 74-77.

[16]. Marli, A. R. and Denise, Garcia de Santana(2006) How and why to measure the germination process? Rev.bras. Bot. 29(1):

[17]. Moyib, O.K., Gbadegesin, M. A., Aina, O.O. and Odunola, O. A. 2008. Genetic variation within a collection of Nigerian accessions of African yam bean (Sphenostylis sternocarpa) revealed by RAPD primers. African Journal of Biotechnology 7(12): 1839-1846.

[18]. Nwokolo, E. A. (1996). The need to increase consumption of pulses in the developing world. In: Nwokolo, E. and Smarts, J. (eds.) Food and feed from legumes and oil seeds. Chapman and Hall,London. pp. 3-11.

[19]. Ogbo, E.M.(2009).Effects of diesel fuel contamination on seed germination of four crop plants-Arachis hypogaea, Vigna unguiculata, Sorghum bicolor and Zea mays. Afr. J. Biotechnology. 8(2): 250-253.

[20]. Okeola, O. G. and Machuka, J. (2001). Biological effects of African yam bean lectin on Clavigralla tomentosicollis (Hemiptera:Coreidae) 94:28-34.

[21]. Okigbo, B. N. (1973). Introducing the yam bean (Sphenostylis sternocarpa (Journal of Economic Entomology)(Hochst ex. A. Rich) Harms. Proceedings of the first IITA Grain Legume Improvement Workshop 29 October-2 November 1973 Ibadan. Nigeria. pp 224-238

[22]. Okonokhua, B.O., Ikhajiagbe, B., Anoliefo, G.O., Emede, T.O.(2007). The Effect of Spent Engine Oil on Soil Properties and Growth of Maize(Zea mays L.). J. Appl. Sci. Environ. Manage. 11(3): 147-152.

[23]. Okpara, D. A., and Omaliko, C. P. E. (1997). Response of African yam bean (Sphenostylis sternocarpa) to sowing date and plant density. Indian Journal of Agriculture Science 67:220-221.

[24]. Porter, D.(1992). Economic botany of Sphenostylis (Leguminosae). Eco. Bot. 46(3):262-275.

[25]. Potter, D and Doyle, J.J.(1992). Origin of African yam bean (Sphenostylis sternocarpa ,Leguminosae): evidence from morphology isozymes chloroplast DNA and Linguistic. Eco. Bot.46:276-292.

[26]. Saka, J.O., Ajibade, S.R.,Adeniyan, O.N.,Olowoyo, R.B., Ogunbodede, B.A.(2004). Survey of underutilized grain legume production systems in the Southwest Agricultural zone of Nigeria. Agric. Food Inf. 6:93-108.

[27]. Srujana, K., and Anisa, B.K.(2010). Toxicity of Spent Oil Contaminants On Dolichos lablab L. and Abelmoschus esculentus L. The Ecosean 4(1):133-136

[28]. Togun, A.O., Egunjobi, J.K.,(1997). Reproductive development and seed yield in African yam bean .Niger.J.Sci, 2:29-35 